\title{
FEATURES OF THE FORMATION AND BECOMING OF PHILOSOPHICAL CONCEPTS IN ENGLISH LANGUAGE AS A REFLECTION OF CARDINAL CHANGES IN SOCIAL DEVELOPMENT
}

\author{
Denis Bakhtiyorovich Sadullaev
}

Bukhara State Medical Institute Named After Abu Ali Ibn Sino, Uzbekistan

\section{ABSTRACT}

This article is aimed at a historical and linguistic analysis of the formation of English philosophical terms. The process of the formation of the English nation, which was intensively continuing during the analyzed period, proceeded in parallel with the spread of both oral and written national English. During the analyzed period, the vocabulary of the English language includes a significant number of new words; at the same time, both the process of borrowing words from ancient and modern languages and the entire system of word production are activated. The article also makes an attempt at the author's interpretation of the problem of the peculiarities of the formation and development of the English philosophy of the Renaissance (XYI-XYII centuries) in the aspect of the categorical-conceptual language from the point of view of philosophy.

KEYWORDS: - Vocabulary, concept, philosophical category, philosophical theoretical knowledge, Renaissance, latinisms, national English language, English philosophy, sublanguage of philosophy, thematic groups.

\section{INTRODUCTION}

The process of the formation of the English nation, which was intensively continuing during the period under review, proceeded in parallel with the spread of both oral and written national English. This factor external to the language system had a great influence on the development of the literary English language. The expansion of the functions of the English national literary language during the formation and stabilization of the nation could not be realized without a significant replenishment of its vocabulary base. During the analyzed period, the vocabulary of the English language includes a significant number of new words; at the same time, both the process of borrowing words from ancient and modern languages and the entire system of word production are activated.

The originality of the era and the state of the language are clearly visible in a detailed analysis of the thematically organized vocabulary of a philosophical nature. We add that the concepts, and, therefore, the words that expressed them, were formed in complex relationships with religion, the influence of which was great; practice itself (major geographical discoveries, scientific and technical progress, expanding the scope of the orbis terranum) caused the need to subordinate philosophical thought to practice, therefore, whole groupings of words are born in accordance with established social practice and 
CURRENT RESEARCH JOURNAL OF PEDAGOGICS 2(12): 171-178,

December 2021 DOI: https://doi.org/10.37547/pedagogics-crjp-02-12-34

ISSN 2767-3278

(C)2021 Master Journals

Crossref dof 81 Google

Accepted 26 $6^{\text {th }}$ December, 2021 \& Published 31 ${ }^{\text {th }}$ December, 2021

the approval of thematic series of categories reflecting the objective world.

All innovations of the research period are the most important terms of philosophy, among which one should, for example, highlight the designation of the most important philosophical category - "concept". The emergence of this category in the era of the late Renaissance is not accidental, since its appearance reflects the highest degree of development of philosophical thought and testifies to its ability to abstract. Intensive and purposeful enrichment of the conceptual apparatus of philosophy (this especially applies to such concepts as "method", "categories of cognition", "space and time", "interconnection and opposition") suggests the intensive development of philosophical trends in the further development of these categories. The reason for this, in our opinion, was the outlined peculiar turn towards epistemology as opposed to the metaphysical-ontological scholasticism of the Middle Ages, a turn that constituted one of the central points of philosophical thought of the late Middle Ages and the Renaissance.

The world outlook struggle also determined the nature of scientific literature and language of the XIV-XVII centuries. Philosophical theoretical knowledge, reflected in specially developed concepts and categories, made it possible for a deep and holistic view of the world, of its general laws and interconnections.

\section{Methods}

The main source of the formation of philosophical categories and concepts at this stage is Latin, therefore the basis of the vocabulary base of the philosophy of the Renaissance is Latinisms, and not the original element. This is a manifestation of the peculiarity of the national English language, in contrast, for example, from Russian, in which, according to Danilenko, the basis of any term-nosystem is made up of primordial Russian names. The quantitatively prevailing lexical units of Romance origin fulfill a social order of great importance in English: they designate precisely the main philosophical categories (being, movement, individual and general, space and time, unity and opposites, materiality)

Thus, during the period under study, the number and content of the main scientific categories increases and the content of these categories is increasingly approaching a complete and comprehensive reflection of the objective world. The basis for studying the philosophical vocabulary of the English language, as indicated above, is precisely the content side of each word. It follows from what has been said that the structural and functional analysis of the layered composition of philosophical texts is aimed at determining those implicit connections that appear between different parts of speech within this vocabulary.

When considering issues related to trends in the development and replenishment of the vocabulary of a language, one must always remember about linguistic contacts and their influence on each other, for language is a generous and reliable source of knowledge of the history of the life of a people; it preserves, in a specific manifestation, the age-old assets of the material and spiritual culture of the people - the creator of the language, as well as, to a certain extent, the assets of other languages with which it contacts.

Analysis of linguistic material by the method of continuous sampling made it possible to identify 30 thematic groups of vocabulary of a philosophical nature with the meaning: "real and potential being", "matter", "spirit", "difference and identity", "part and whole", "consciousness", " space "," time "," freedom and necessity "," essence and phenomenon "," necessity and chance "," method "," method of cognition "," 
CURRENT RESEARCH JOURNAL OF PEDAGOGICS 2(12): 171-178,

December 2021 DOI: https://doi.org/10.37547/pedagogics-crjp-02-12-34

ISSN 2767-3278

(C)2021 Master Journals

Crossref do: 81 Google

Accepted 26 $6^{\text {th }}$ December, 2021 \& Published 31 ${ }^{\text {th }}$ December, 2021

practice "," form and content "," movement "," interconnection and opposite "," quality and quantity "," materiality "," individual, particular and universal "," possibility and reality "," finite and infinite "," cause and effect "," rational knowledge "," sensory knowledge ", a group of terms of a social nature, general ethical concepts, properties of human character, properties of human intelligence, types of human relations.

The general corpus of words of the philosophical vocabulary for this period amounted to 1439 units. The foundation of the vocabulary of English philosophy was laid back in the old English period. We have fixed 15 groups out of a total of 30: these are thematic groups "real and potential being", "space", "time", "freedom and necessity", "essence and phenomenon", "method of cognition", "practice "," form and content "," movement "," quality and quantity "," materiality "," matter "," individual, special and universal "," rational cognition ", a group of terms of a sociological nature.

From the point of view of chronology, the words of these TGs were recorded mainly in the old English period, but their especially intensive replenishment dates back to the XIV-XV centuries, with the highest point in the XIV century, when the core of the English philosophical vocabulary was actively formed. A detailed analysis of the entire corpus of vocabulary revealed an interesting fact: even in the 13th century, the words of such TGs as "possibility and reality", "finite and infinite", "practice" were not noted in the English dictionary.

From the point of view of etymology, the largest number of receipts falls on the vocabulary of Romance origin: Latin - 553 words, including - a) direct borrowings - 224 words; b) penetrated through the intermediary language French - 329 units; direct French borrowings - 71 words (that is, out of a total of 1439 words - 43.4 percent of the words are of Romance origin).

Comparison of the ratio of primordial and borrowed vocabulary in our case highlights the criteria of "primordialness-non-primacy" as relevant for a given language, which can serve as a basis for its use as one of the differential features in stratification of the vocabulary of the English language.

Analysis of the material shows that the formation of the core of philosophical vocabulary finally took place in the XIV-XV centuries, and in the XVI-XVII centuries. there was a process of further replenishment, expansion, polishing of the conceptual circle of philosophical categories, according to their etymology ascending, for the most part, to antiquity. The incessant flow of borrowings, which led to the improvement of the language of English philosophy and, mainly, to the completion of its formation, is evidenced by a significant replenishment in the 16th-17th centuries. 20 thematic groups out of a total of 31 . It was during this historical period that such new lexical units as fact "fact", concept "concept", notion "concept", reflex "reflection", reminiscence "memory", modality "modality", antecedence "antecedent", entity "integrity", expectation "expectation", ratiocination "reasoning", education "education", modesty "modesty", credit "trust", decorum "decorum" etc. These are the most important terms of English philosophy from the point of view of their semantic and functional load and social value. Among them, one can single out the innovation concept [ad.L.conceptionem, conceptus], which has become the basic designation of the most important philosophical category "concept", the appearance of which in the English literary language is not accidental in this era, for it reflects the highest stage of development of the philosophical thoughts and testifies to its ability to abstract.

Greekisms (21 words) coincide in semantic 
CURRENT RESEARCH JOURNAL OF PEDAGOGICS 2(12): 171-178,

December 2021 DOI: https://doi.org/10.37547/pedagogics-crjp-02-12-34

ISSN 2767-3278

(C)2021 Master Journals

Crossref do: 81 Google

Accepted $26^{\text {th }}$ December, 2021 \& Published $31^{\text {th }}$ December, 2021

features with Roman borrowings and are used to denote concepts of categories of English philosophy -

The contribution of other languages to the studied vocabulary is small. The primordial vocabulary does not play a noticeable role among the nouns of a philosophical nature of the analyzed TG. Lexical units of a hybrid nature are not a specific feature of the studied material. As a result, it can be stated that the main source of the formation of thematic groups of philosophical vocabulary at the stage of their formation is Latin, therefore the basis of the vocabulary fund of categories of English philosophy is Latinisms, and not the original element. We pay special attention to this because it later predetermined the relative advantage of the English language, when this language began to be put forward in the XX century as the international world language N1, because it had a lot of the same, consonant, understandable, in common with other internationally -world languages: French, Spanish and their "brothers" - Italian, Portuguese, etc. Quantitatively prevailing words of Romanesque origin fulfill a social order of great importance: they denote the basic concepts of English philosophical categories, as evidenced by the fact that these words penetrated into the language not as separate isolated lexical units, but were included in it in large, thematically integral semantic-structural groups, which is the result of French-English linguistic contacts and long-term bilingualism. The Norman conquest of Great Britain (in the 11th century) left deep traces in the English language. It is in the sphere of philosophical vocabulary that this influence is obvious, and it had a serious impact on the formation, formation and, more broadly, the further evolution of the entire terminology system of English philosophy during the period of the formation of the English nation. Convincing evidence of this is the influence of the French language in the period of the XIII-XIV centuries. and its role in the social and social environment of Great Britain after its conquest by William the Conqueror, influence on the vocabulary of the English language in general, and, in particular, on the language of philosophical writings of the era under study.

There can be no doubt about the great value of the analysis of the Norman linguistic contribution for solving the issue of the role of the French language in the context of extralinguistic factors of the era, as an accompanying one, in the formation of the main core of the philosophical vocabulary of the English national literary language of the period of the XIV-XVII centuries. (especially - XIV-XV centuries). The history of the English literary language cannot but reckon with this: the influence of the French language on English, as you know, did not stop after the separation of England from Normandy - just purely political factors gave way to cultural and historical factors, but the impact did not become from this less. What explains the significance of the influence of the Norman Conquest on the English language, although it was short-lived? The point is not only in linguistic factors, but also in extralinguistic factors, i.e. starting from the XIII century, England ceased to be a distant outskirts in relation to Central Europe and began to intensify the borrowing of the entire European culture, which was embodied, first of all, in France.

For the period of formation (XIV-XV centuries) and enrichment (XVI-XVII centuries) of English philosophical vocabulary, the replenishment of thematic series with Romanisms and especially Latinisms is due to the fact that, firstly, this historical period of time was the beginning of a systematic presentation. the first scientific works in English, and, consequently, the beginning of the formation on English soil of the semantic series of modern English philosophical terminology. The preference for Latinisms to 
CURRENT RESEARCH JOURNAL OF PEDAGOGICS 2(12): 171-178,

December 2021 DOI: https://doi.org/10.37547/pedagogics-crjp-02-12-34

ISSN 2767-3278

(C)2021 Master Journals

Crossref doi) 81 Google

Accepted 26 $6^{\text {th }}$ December, 2021 \& Published 31 ${ }^{\text {th }}$ December, 2021

enrich the vocabulary base, in particular philosophical vocabulary, is explained by the fact that the first philosophical works in English relied on the canonized Latin grammatical scheme, which until the 17th-18th centuries was recognized in England as almost the only basic science of language and as a model perfection and a standard to follow, and Latin itself was the center around which the search for the norm of the English literary language was conducted.

Intensive character of admission to the TG: general properties of a human character (memory "memory", motive "motive", speculation "reasoning", communication "connection", fantasy "imagination"), "category of cognition" (sense "feeling", apprehension "feeling", image "image", appreciation "assessment", reflex "reflection"), "method" (anticipation "anticipation", expectancy "expectation", presension "presentation", inference "guess, conclusion"), "space" , "time" (moment "moment", eternity "eternity", period "period", concomitance "accompanying", perennity "eternity", vacuum "vacuum", vacuity "emptiness"), "interrelation and opposition" (contradiction ", opposition" opposition ", correlation" correlation ", compendium" compendium ") suggests an intensive development of philosophical thought of the period of research in terms of further development of categories of philosophy.

For each period of the history of the English language, there was a characteristically defined circle of nouns to designate a particular concept of the sublanguage of philosophy.

A characteristic feature of the formation of the concepts of philosophy is that in the Old English period the vocabulary of 15 categories is formed out of the total number of 30 that we have identified. Even in the 13th century, the words of thematic groups "possibility and reality", "finite and infinite", "practice" ... And only the period of the XIV-XV centuries. testifies:

a) on the final design of the composition of all TGs (essence - categories) of philosophy;

b) the formation, in the sense of words, of those abstract concepts that are inherent in the language of philosophy.

Qualitative and quantitative data on the formation of philosophical vocabulary and the formation of thematic groups indicate that in the future, i.e. XVI-XVII centuries, the number and content of the main scientific categories is enriched, the totality of which is increasingly approaching a complete and comprehensive reflection of the objective world. Our analysis of the formation of the base of philosophical categories clearly reveals the stages of movement of social and scientific thought in the understanding of philosophical categories that actually sound in the XVI-XVII centuries, but their origins go back to antiquity.

\section{Conclusion}

So, philosophical terminology appears before us as a single integral system, subordinate to the objective laws of history and thinking, reflecting the really existing dialectical relationship and further development of the most important philosophical concepts, worldview of representatives of the era. The Renaissance epoch decisively influenced not only the content, but also the composition of the philosophical dictionary, as evidenced by the appearance in the 16th-17th centuries. a large number of words to express the concepts and ideas of a new worldview and worldview in the light of the discoveries of the era.

When describing the history of the formation of philosophical vocabulary, it is customary to observe the chronological sequence in order to capture the internal regularity inherent in this process and, at the same time, pay tribute to the 
CURRENT RESEARCH JOURNAL OF PEDAGOGICS 2(12): 171-178,

December 2021 DOI: https://doi.org/10.37547/pedagogics-crjp-02-12-34

ISSN 2767-3278

(C)2021 Master Journals

Crossref dof 81 Google

Accepted 26 $6^{\text {th }}$ December, 2021 \& Published 31 ${ }^{\text {th }}$ December, 2021

peculiarities of a particular work and its author, a period in the development of the language. This approach is the basis of our research.

\section{REFERENCES}

1. Budagov R.A. What is language development and improvement? - M .: Nauka, 1977- P.76.

2. Yartseva V.N. Development of the national literary English language. M., 1964.- S. 122.

3. Ufimtseva A.A. Word in the lexico-semantic system of the language. -M. Science, 1974 - P. 13.

4. Shadmanov K. Features of English philosophical thought and vocabulary of the XIV-XVII centuries. T .: TFI, 2003.- P. 66.

5. Donskoy V.F. Verbal phraseological units denoting the beginning and end of a person's life in the language of the New England period: Abstract of the thesis ... Candidate of Philological Sciences. -M., 1977. -S. 23.

6. Krasilnikova M.S. Origin, semantic structure and some syntagmatic connections of English nouns of a literary and book nature: Abstract of the thesis ... candidate of philological sciences. - M., 1978 --- P. 16.

7. Vinogradov V.V. Lexicology and Lexicography. Selected work. - M .: Nauka, 1977 - S. 312.

8. Ufimtseva A.A. Word in the lexico-semantic system of the language. - M. Nauka, 1968 .-1980 - S. 580.

9. Ufimtseva A.A. Word in the lexico-semantic system of the language. -M. Science, 1968 .-P. 251.

10. Yartseva V.N. Development of the national literary English language. -M .: Science. 1969 - p. 95.

11. Sadullaev D. B. Philosophical understanding of terms and concepts by an author as an object of linguistic investigations //Молодой ученый. - 2020. - №. 22. - С. 627-631.

12. Sadullaev D. B. (2020). Historical reality concepts. ISJ Theoretical \& Applied Science, 04 (84), pp. 414- 419

13. Sadullaev Denis Bakhtiyorovich 2020. Concerning the history, formulation and interpretation of the conversion's issue in english language. International Journal on Integrated Education. 3, 3 (Mar. 2020), 9597.

DOI:https://doi.org/10.31149/ijie.v3i3.96.

14. Sadullaev D. B., Ostonova S. N., Shodiev S. S. Interpretation of philosophical terms and concepts as an essential subject for linguistic researches of xix-xx centuries, held in Russia and Europe // ACADEMICIA: An International Multidisciplinary Research Journal. Year : 2020, Volume : 10, Issue : 10, First page : ( 590) Last page : (598), Online ISSN : 2249-7137. Article DOI : 10.5958/2249-7137.2020.01171.4

15. Sadullaev, Denis Bakhtiyorovich Terminology as a separate scientific field and its actual position in modern linguistics // ACADEMICIA: An International Multidisciplinary Research Journal. Year : 2020, Volume : 10, Issue : 11, First page : ( 1964) Last page : (1973), Print ISSN : 00000000. Online ISSN : 2249-7137. Article DOI : 10.5958/2249-7137.2020.01486.X

16. Sadullaev, Denis B. "Problems of Understanding Philosophical Text as a Linguistic Phenomenon." JournalNX, vol. 6, no. 06, 2020, pp. 128-136.

17. Шадманов Курбан Бадриддинович, \& Садуллаев Денис Бахтиерович (2019). Из истории становления системы основных понятий английской философии. Наука и образование сегодня, (10 (45)), 40-43.

18. Садуллаев Д. Б. Форма существования 
CURRENT RESEARCH JOURNAL OF PEDAGOGICS 2(12): 171-178,

December 2021 DOI: https://doi.org/10.37547/pedagogics-crjp-02-12-34

ISSN 2767-3278

(C)2021 Master Journals

Crossref do: 81 Google

Accepted 26 $6^{\text {th }}$ December, 2021 \& Published 31 ${ }^{\text {th }}$ December, 2021

языка //81.2 г (5У) Ш 16. - 2019. - С. 201.

19. Sadullaev Denis Bakhtiyorovich Linguistic combinatory processes "assimilation" and "borrowing" as a basis for the development of modern english terminology // Asian Journal of Multidimensional Research (AJMR). Year : 2020, Volume : 9, Issue : 11, First page : ( 33) Last page : (38), Online ISSN : 2278-4853. Article DOI : 10.5958/2278-4853.2020.00297.9

20. Shadmanov Kurban Badriddinovich, Sadullaev Denis Bakhtierovich From the history of the formation of the system of basic concepts of English philosophy // Science and education today. 2019. No. 10 (45).

URL: https://cyberleninka.ru/article/n/iz-istoriistanovleniya-sistemy-osnovnyh-ponyatiyangliyskoy-filosofii

21. Obidovna, D. Z., \& Sadullaev Denis. (2021). FORMULAS OF SPEECH ETIQUETTE IN A GENDER-ENGINEERED COMMUNICATION STRATEGY. CENTRAL ASIAN JOURNAL OF THEORETICAL \& APPLIED SCIENCES, 2(6), 511. Retrieved from http://cajotas.centralasianstudies.org/index. php/CAJOTAS/article/view/180

22. Bakhtiyorovich, S. D. (2021). TERM: DEFINITION OF THE CONCEPT AND ITS ESSENTIAL FEATURES. CENTRAL ASIAN JOURNAL OF THEORETICAL \& APPLIED SCIENCES, 2(6), 12-18. Retrieved from http://cajotas.centralasianstudies.org/index. php/CAJOTAS/article/view/181

23. Бахтиерович, С. Д. (2021). ТЕРМИНОЛОГИЧЕСКИЕ ЕДИНИЦЫ СКВОЗЬ ПРИЗМУ КОМБИНАТОРНОКОМПОНЕНТНОГО И ФУНКИОНАЛЬНОСИНТАКСИЧЕСКОГО АНАЛИЗА. CENTRAL ASIAN JOURNAL OF THEORETICAL \& APPLIED SCIENCES, 2(6), 23-29. Retrieved from

http://cajotas.centralasianstudies.org/index. php/CAJOTAS/article/view/183

24. Sadullaev, D. B. (2021). Renaissance And Renaissance Philosophical Texts Through The Prism Of Historical Approach. The American Journal of Social Science and Education Innovations, 3(05), 364-371. https://doi.org/10.37547/tajssei/Volume03 Issue 05-67

25. Садуллаев Д. Б. Philosophical understanding of terms and concepts by an author as an object of linguistic investigations //Молодой ученый. - 2020. - №. 22. - С. 312.

26. Sadullaev D. B. (2020). Concerning the history, formulation and interpretation of the conversion's issue in english language. International Journal on Integrated Education, 3, 3 (Mar. - 2020

27. Denis Bakhtiyorovich Sadullaev. (2021). PHILOSOPHICAL TERMS AND CONCEPTS AN THEIR FUNCTIONAL UNIQUENESS THROUGH THE PRISM OF LEXICAL ANALYSIS OF THE RENAISSANCE. CURRENT RESEARCH JOURNAL OF PHILOLOGICAL SCIENCES (2767-3758), 2(11), 22-28. https://doi.org/10.37547/philological-crjps02-11-07

28. Denis Bakhtiyorovich Sadullaev. (2021). THE LEXICON OF ENGLISH PHILOSOPHY IN THE PLANE OF THE PHILOSOPHY OF THE LANGUAGE. CURRENT RESEARCH JOURNAL OF PEDAGOGICS, 2(11), 41-46. https://doi.org/10.37547/pedagogics-crjp02-11-10

29. Bakhtiyorovich, S. D. (2021). The Influence of Philosophy, Philology and Linguistics upon Terminological Investigations. CENTRAL ASIAN JOURNAL OF THEORETICAL \& APPLIED SCIENCES, 2(6), 68-74. Retrieved from 
CURRENT RESEARCH JOURNAL OF PEDAGOGICS 2(12): 171-178,

December 2021 DOI: https://doi.org/10.37547/pedagogics-crjp-02-12-34

ISSN 2767-3278

(C)2021 Master Journals

Crossref doi) 81 Google

Accepted 26 ${ }^{\text {th }}$ December, $2021 \&$ Published 31 ${ }^{\text {th }}$ December, 2021

http://cajotas.centralasianstudies.org/index.

php/CAJOTAS/article/view/195

30. Bakhtiyorovich, S. D. (2021). Peculiarities of Applying the Historical - Functional Approach in Literature. CENTRAL ASIAN JOURNAL OF THEORETICAL \& APPLIED SCIENCES, 2(6), 62-67. Retrieved from http://cajotas.centralasianstudies.org/index. php/CAJOTAS/article/view/194 